\title{
Free vastus lateralis muscle flap transplantation for postoperative chronic empyema: retrospective analysis of eight case series
}

\author{
Yongyong $\mathrm{Wu}^{1}{ }^{\wedge}$, Zhongliang $\mathrm{He}^{1}$, Chun $\mathrm{Zhang}^{2}$, Yiyang Liu ${ }^{2}$, Weihua $\mathrm{Xu}^{3}$, Guoxing Chen ${ }^{1}$, Zhijun Liu ${ }^{1}$, \\ Shunxin Xin ${ }^{1}$, Lei Wang ${ }^{1}$ \\ ${ }^{1}$ Department of Cardiothoracic Surgery, Tongde Hospital of Zhejiang Province, Hangzhou, China; ${ }^{2}$ Department of Orthopaedic Surgery, Tongde \\ Hospital of Zhejiang Province, Hangzhou, China; ${ }^{3}$ Department of Respiratory Medicine, Tongde Hospital of Zhejiang Province, Hangzhou, China \\ Contributions: (I) Conception and design: Y Wu, Z He; (II) Administrative support: C Zhang, Y Liu; (III) Provision of study materials or patients: G \\ Chen, Z Liu; (IV) Collection and assembly of data: Y Wu, Z Liu; (V) Data analysis and interpretation: Y Wu, Z He, Z Liu; (VI) Manuscript writing: \\ All authors; (VII) Final approval of manuscript: All authors. \\ Correspondence to: Zhongliang He, MD, Professor. Department of Cardiothoracic Surgery, Tongde Hospital of Zhejiang Province, No. 234 Gucui \\ Road, Xihu District, Hangzhou 310012, China. Email: doctorhzl@163.com.
}

Background Postoperative chronic empyema (PPE) remains a complex challenge for thoracic surgeons. We retrospectively investigated patients with PPE who were treated with free vastus lateralis muscle flap transplantation, and report our results.

Methods: Eight patients with PPE and persistent bronchopleural fistula (BPF) treated in our hospital from January 2015 to June 2019 were retrospectively analyzed, the time since onset of empyema ranged from 5 to 72 months. The operation was performed in two stages, stage I surgery included empyema debridement, rib resection drainage or open-window thoracostomy (OWT), meanwhile, BPF was treated under bronchoscope. Stage II surgery included obliteration of the pleural space by free muscle flap transplantation. The keys to the operation are thorough debridement, closure of the BPF, and complete obliteration of the residual pleural space. The challenge lies in the anastomosis of the lateral femoral circumflex artery and vein that supply the vastus lateralis muscle flap to the thoracodorsal vessels.

Results: The free muscle flaps survived in all eight patients. The abscess cavity was completely obliterated with the muscle flap. Good efficacy was achieved with primary wound healing. No serious perioperative complications were reported. No empyema recurrence, atrophy, infection, or necrosis of the muscle flap was seen during the 18- to 72-month follow-up.

Conclusions: The vastus lateralis muscle flap has a large volume with good blood supply and strong antibacterial ability. It can be used for effective obliteration of a large residual cavity caused by empyema and maintains a good thoracic shape. It is an ideal choice for the treatment of postoperative chronic refractory empyema.

Keywords: Chronic empyema; free vastus lateralis muscle flap; bronchopleural fistula (BPF); open-window thoracostomy (OWT)

Submitted Jan 30, 2021. Accepted for publication Mar 17, 2021.

doi: $10.21037 /$ apm-21-261

View this article at: http://dx.doi.org/10.21037/apm-21-261

$\wedge$ ORCID: 0000-0001-6080-309X. 


\section{Introduction}

Postoperative chronic empyema (PPE) is postoperative chronic infection of the pleural cavity with various surgical causes and is very difficult to treat if accompanied by bronchopleural fistula (BPF). PPE has a protracted course of the disease and may gradually develop into chronic empyema (1). The treatments of this type of empyema include rib resection drainage, decortication, and openwindow thoracostomy (OWT). These procedures are conducive to controlling infection and cleaning the abscess cavity, but the existence of a residual cavity and BPF often lead to recurrence of empyema (2). Obliteration of the residual cavity with a tissue flap is an effective radical treatment for chronic empyema. The vastus lateralis muscle flap is autologous tissue with sufficient volume, good blood supply, and strong antibacterial ability, all of which help obliterate a large residual cavity. The use of the vastus lateralis muscle flap has been reported in a foreign journal (3). In the past 5 years, our hospital has successfully treated eight patients with postoperative chronic refractory empyema by free vastus lateralis muscle flap transplantation. This paper summarizes our experience.

We present the following article in accordance with the AME Case Series Checklist (available at http://dx.doi. org/10.21037/apm-21-261).

\section{Methods}

\section{General materials}

A total of eight patients treated in our hospital from January 2015 to June 2019 were selected. They were six men and two women aged 23 to 70 years old. All patients had a history of more than two operations in other hospitals. The primary diseases included lung malignant tumors $(n=4)$, lung cysts $(n=2)$, pulmonary aspergillus $(n=1)$, and tuberculous pleurisy $(\mathrm{n}=1)$. All patients had bronchial stump fistula or BPF. Two patients with bronchial stump fistula and segmental bronchial stump fistula were treated with stent implantation in other hospitals, six patients had BPF and alveolopleural fistula (diameter $>3 \mathrm{~mm}$ in two patients and $\leq 3 \mathrm{~mm}$ in four patients). Six patients had long-term continuous drainage via a chest tube, and two patients had OWT with regular dressing changes. The details of each patient's original disease, previous operations, BPF, and described in the following table (Table 1). The study was conducted in accordance with the Declaration of Helsinki (as revised in 2013). The study was approved by institutional ethics board of Tongde Hospital of Zhejiang Province (No.KTSC2017229) and individual consent for this retrospective analysis was waived. Data were collected between January 2015 to June 2019.

\section{Statistical analysis}

All the data, such as preoperative profiles, surgical findings, postoperative images, outcomes, and complications, were recorded. All the patients were followed up through outpatient service, with an average follow-up time of 18-72 months. Statistical analysis was performed using Windows SPSS 22.0 software. For descriptive statistics, quantitative data was represented as mean $\pm \mathrm{SD}$ (or SE), and discrete data was represented as frequencies.

\section{Surgical procedures}

\section{Empyema debridement + rib resection drainage or OWT + closure of the fistulas}

The surgical management was selected depending on the degree of empyema infection in the pleural cavity in each patient (this step was not required in patients who had already received OWT in other hospitals). Patients with mild contamination underwent rib resection drainage whereas patients with severe infection underwent OWT procedure (Figure 1). During the first surgery, 2 segmental ribs were resected, and necrotic tissues and pus on the surface of the membrane were removed. The size of the abscess cavity and the number and diameter of BPFs were determined. Meanwhile, bronchoscopy was also performed routinely to assess the location and size of the BPF during operation. Fistulas smaller than $3 \mathrm{~mm}$ could be left untreated or closed by injection of medical glue under direct vision. Fistulas larger than $3 \mathrm{~mm}$ were managed by a one-way endobronchial valves (EBV) implantation under guidance of bronchoscopy. After the closure of fistulas was completed, the lung was reinflated to confirm no air leakage. Hydrogen peroxide, iodophor solution, and physiological saline were used to wash the abscess cavity repeatedly until it appeared clean. The incision was closed for the patients of drainage, and two chest tubes were placed for continuous irrigation about 2 weeks after the operation. For the patients of OWT, dressings with iodoform gauze were done daily for 3-4 weeks.

Stage II surgery for obliteration of the residual cavity with muscle flap was performed until the following postoperative conditions were met: hemoglobin (Hb) $100 \mathrm{~g} / \mathrm{L}$, plasma 


\begin{tabular}{|c|c|c|c|c|c|c|c|c|c|c|c|c|c|c|}
\hline & Sex & $\begin{array}{c}\text { Age } \\
\text { (years) }\end{array}$ & Primary diseases & Side & Type of surgery performed in other hospitals & $\begin{array}{l}\text { Transected muscles } \\
\text { previously }\end{array}$ & $\begin{array}{l}\text { Time since onset of } \\
\text { empyema (months) }\end{array}$ & $\begin{array}{c}\text { Fistula } \\
\text { size }(\mathrm{mm})\end{array}$ & OWT & $\begin{array}{l}\text { Size of abscess } \\
\text { cavity }(\mathrm{cm})\end{array}$ & Bacterial culture & $\begin{array}{l}\text { Operating } \\
\text { time (h) }\end{array}$ & $\begin{array}{l}\text { Length of hospital } \\
\text { stay (days) }\end{array}$ & $\begin{array}{l}\text { Postoperative } \\
\text { complications }\end{array}$ \\
\hline 1 & Male & 55 & $\begin{array}{l}\text { Pulmonary Aspergillus } \\
\text { bacteria pellet }\end{array}$ & $\mathrm{R}$ & $\begin{array}{l}\text { Upper lung resection + closed drainage + } \\
\text { bronchial stent implantation }\end{array}$ & $\begin{array}{l}\text { Latissimus dorsi, serratus } \\
\text { anterior }\end{array}$ & 24 & 5 & No & $8.6 \times 7.5 \times 3.6$ & $\begin{array}{c}\text { Staphylococcus } \\
\text { aureus, Pseudomonas } \\
\text { aeruginosa }\end{array}$ & 5.0 & 43 & No \\
\hline 3 & Male & 70 & $\begin{array}{l}\text { Lung squamous-cell } \\
\text { carcinoma }\end{array}$ & $\mathrm{R}$ & $\begin{array}{l}\text { Upper lung resection + recurrent tracheal } \\
\text { tumor resection + closed drainage }\end{array}$ & $\begin{array}{l}\text { Latissimus dorsi, serratus } \\
\text { anterior }\end{array}$ & 22 & 2 & No & $8.9 \times 6.5 \times 5.0$ & $\begin{array}{l}\text { Stenotrophomonas } \\
\text { maltophilia }\end{array}$ & 6.0 & 53 & No \\
\hline 4 & Male & 63 & pulmonary cyst & L & $\begin{array}{l}\text { Pneumonectomy + partial chest modification } \\
\qquad+ \text { OWT }\end{array}$ & $\begin{array}{l}\text { Latissimus dorsi, serratus } \\
\text { anterior }\end{array}$ & 26 & 4 & Yes & $15.0 \times 10.0 \times 3.9$ & $\begin{array}{l}\text { Enterobacter cloacae, } \\
\text { Proteus mirabilis }\end{array}$ & 5.0 & 31 & No \\
\hline 6 & Female & 30 & pulmonary cyst & L & $\begin{array}{l}\text { Resection of upper pulmonary cyst }+ \\
\text { closed drainage }+ \text { secondary open chest } \\
\text { exploration }\end{array}$ & $\begin{array}{l}\text { Latissimus dorsi, serratus } \\
\text { anterior pectoralis major }\end{array}$ & 74 & 2 & Yes & $13.6 \times 9.2 \times 5.8$ & $\begin{array}{l}\text { Alcaligenes } \\
\text { xylosoxidans }\end{array}$ & 6.5 & 44 & No \\
\hline 7 & Female & 60 & $\begin{array}{l}\text { Thymic carcinoma } \\
\text { with lung invasion }\end{array}$ & $\mathrm{R}$ & $\begin{array}{l}\text { Thymoma resection + recurrent tumor } \\
\text { resection + diaphragm reconstruction + } \\
\text { partial lung resection + obliteration with } \\
\text { pedicle muscle flap }\end{array}$ & $\begin{array}{l}\text { Latissimus dorsi, serratus } \\
\text { anterior }\end{array}$ & 5 & 3 & No & $11.7 \times 6.0 \times 5.4$ & $\begin{array}{l}\text { Streptococcus } \\
\text { anginosus, } \\
\text { Pseudomonas } \\
\text { aeruginosa }\end{array}$ & 5.5 & 55 & No \\
\hline 8 & Male & 58 & $\begin{array}{l}\text { Lung squamous-cell } \\
\text { carcinoma }\end{array}$ & $\mathrm{R}$ & $\begin{array}{l}\text { Right pneumonectomy + injection of a } \\
\text { sclerosing agent. + closed drainage + } \\
\text { obliteration with pedicled omentum }\end{array}$ & $\begin{array}{l}\text { Latissimus dorsi, serratus } \\
\text { anterior }\end{array}$ & 14 & 2 & Yes & $12.0 \times 10.0 \times 5.0$ & $\begin{array}{l}\text { Streptococcus } \\
\quad \text { gordonii }\end{array}$ & 4.5 & 60 & No \\
\hline
\end{tabular}



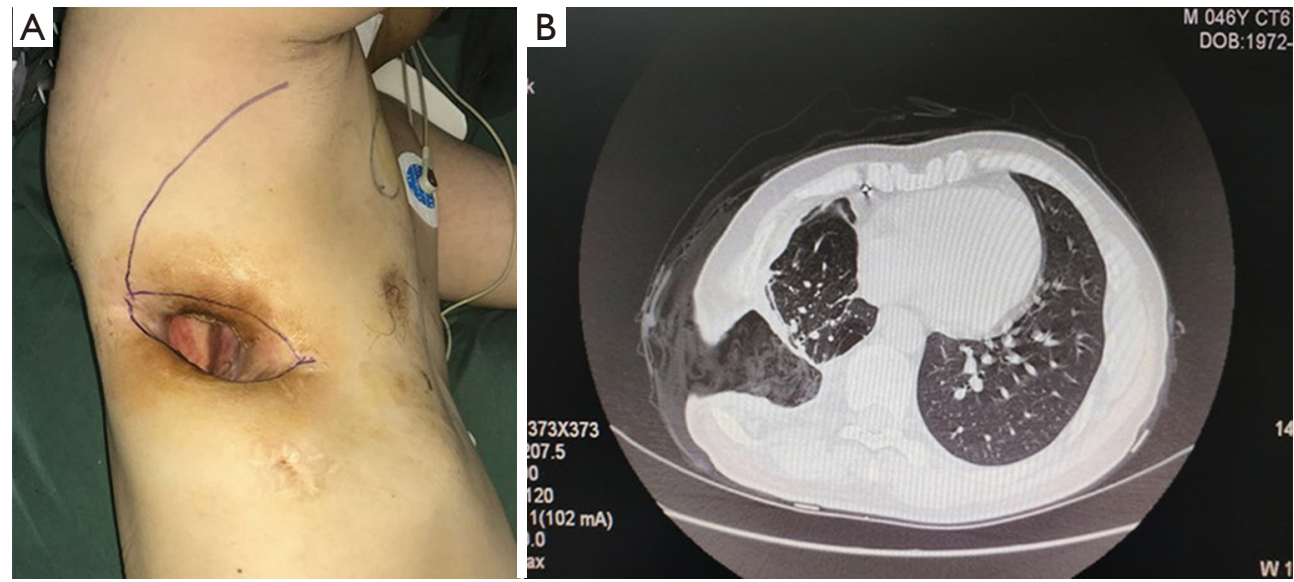

Figure 1 Preoperative images. (A) Appearance and incision design of the chest wall before surgery. (B) Chest CT shows a very large defect in the right chest wall.

albumin $30.0 \mathrm{~g} / \mathrm{L}$, normal body temperature, drainage becoming clean with a falling volume, negative bacterial culture, fresh granulation tissue on the expected wound, and effectively controlled infection. It could take 3 to 4 weeks to meet those conditions. All patients underwent computed tomography angiography (CTA) of the subclavian artery on the affected side and the lower-extremity arteries to understand the patency of the blood vessels and to rule out the atherosclerotic plaque, stenosis, and vascular variation.

\section{Re-debridement + harvest of free muscle flaps}

Under general anesthesia with double-lumen tracheal intubation, the patient was placed in the $30^{\circ}$ or $45^{\circ}$ lateral decubitus position according to the location of the abscess cavity and the harvest of muscle flaps from the lower limbs. There was no need to change the position during the operation. The thoracic abscess cavity was accessed via an incision along the original incision scar for debridement, including removal of blood clots and necrotic tissues in the abscess cavity, scraping of the wall of the abscess with a curette until there was fresh tissue with mild blood oozing, and repeatedly washing the abscess cavity with large amounts of hydrogen peroxide, iodophor solution, and normal saline (Figure 2A). The anesthesiologist was asked to reinflate the lung to ensure no obvious air leakage. Filling the residual cavity with dry gauze after that.

The operative field was re-disinfected and redraped. The axis of the flap was the line connecting the anterior superior iliac spine and the lateral upper edge of the patella. The midpoint of this axis was the exit point of the first perforating branch of the descending branch of the lateral femoral circumflex artery. This point was used as the center, and a fibula flap skin paddle was designed according to the size of the chest wall defect, in order to observe the blood supply of the muscle flap after the operation. The line between the midpoint of the line between the anterior superior iliac spine and the lateral upper edge of the patella and the artery pulse point at inguinal ligament was selected as the body surface projection of the descending branch of the lateral femoral circumflex artery, and the position and course of the vascular pedicle were determined based on this projection. The descending branch of the lateral femoral circumflex artery was exposed in the space between the vastus lateralis muscle and the rectus femoris, and then the artery was dissected proximally to the deep femoral artery, with ligation of the artery branches. The length of the vessel pedicle equaled the length from the point of the descending branch of the lateral femoral circumflex artery to the point where the vessel entered the vastus lateralis muscle. The length was approximately $8 \mathrm{~cm}$ (including one artery and two veins). According to the size of the abscess cavity, an appropriate vastus lateralis muscle flap was designed (Figure 2B). After intact harvest of the free muscle flap, the flap was protected and wrapped with warm normal saline gauze.

\section{Vascular anastomosis}

According to the reconstructed images from the preoperative CTA of the subclavian artery, the thoracodorsal artery and veins (one artery and two veins) in the affected side was dissected and separated as the recipient's blood vessels. The free muscle flap was filled into the abscess cavity, and the 

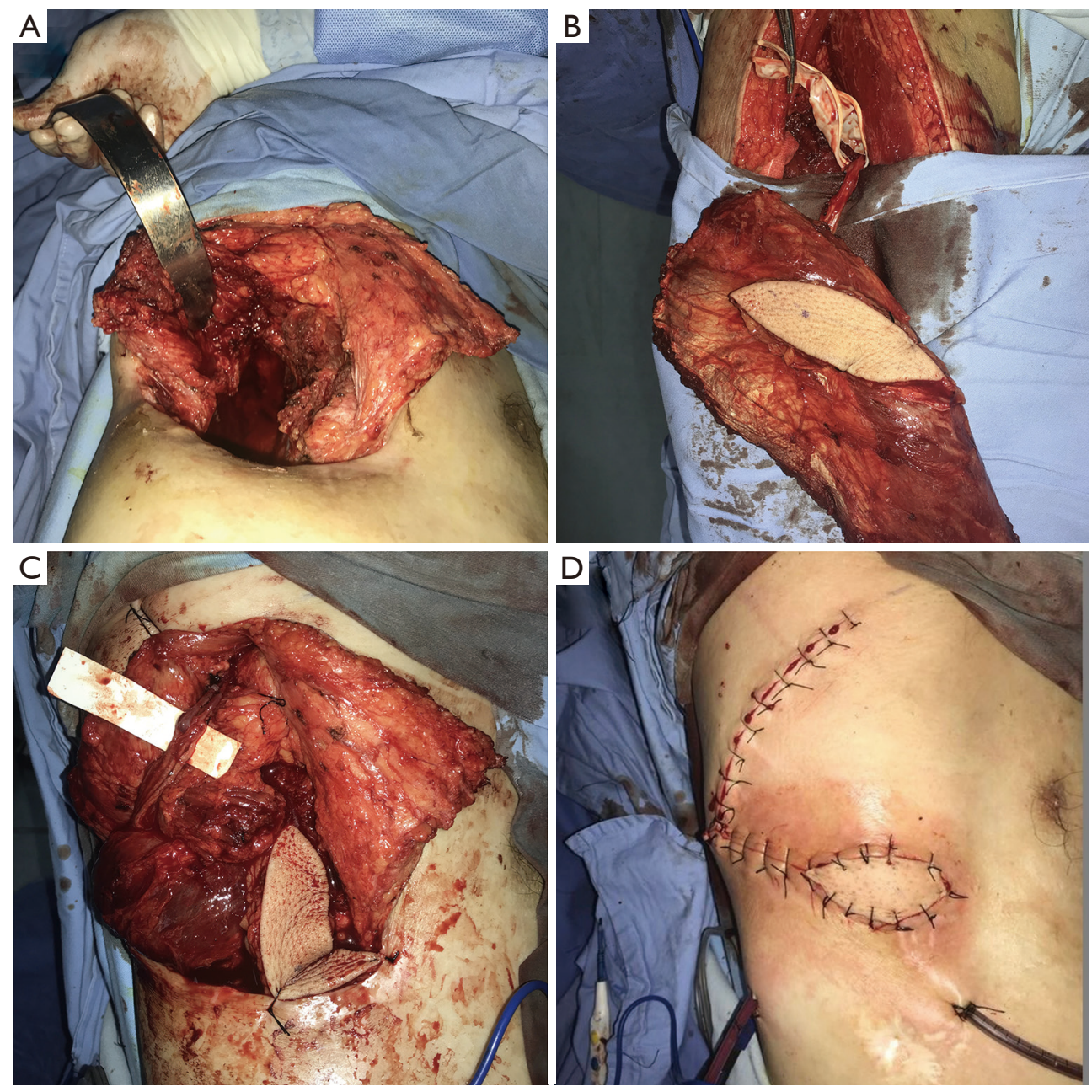

Figure 2 Intraoperative images. (A) Appearance of the chest wall after debridement of the abscess cavity. (B) Harvesting of the vastus lateralis muscle flap. (C) The abscess cavity is filled with the muscle flap, and vascular anastomosis is complete. (D) Appearance of the chest wall immediately after surgery.

artery and veins of the pedicle were anastomosed to the thoracodorsal artery and veins in the recipient area. Then 9-0 prolene sutures were used for anastomosis under the microscope. The anastomosis completion had to ensure that the blood vessels were free of tension and distortion (Figure 2C). A closed chest drainage tube (close to the fistula) and two to three subcutaneous drainage tubes were placed. The muscle flap and chest wall tissue were secured with suture appropriately, and finally the skin paddle and chest wall skin incisions were closed (Figure 2D).

\section{Postoperative precautions}

(I) Anti-infection, anticoagulation with low-molecular- weight heparin and anti-vasospasm with anisodamine treatment were administered (the usage of lowmolecular-weight heparin and anisodamine: once a day and lasted for 1 week).

(II) Four observations: attention should be paid to the skin temperature (at the end of the operation, the skin temperature was about 1 degree lower than normal, and it usually recovered within $3 \mathrm{~h}$ ), color (the skin color of the grafted flap is ruddy, consistent with or slightly redder than the skin of the healthy side), capillary reaction (the skin of the transplanted flap with normal blood supply is ruddy, and turns pale under light pressure. Once the pressure is removed, the compressed area changes from pale to ruddy in 1 

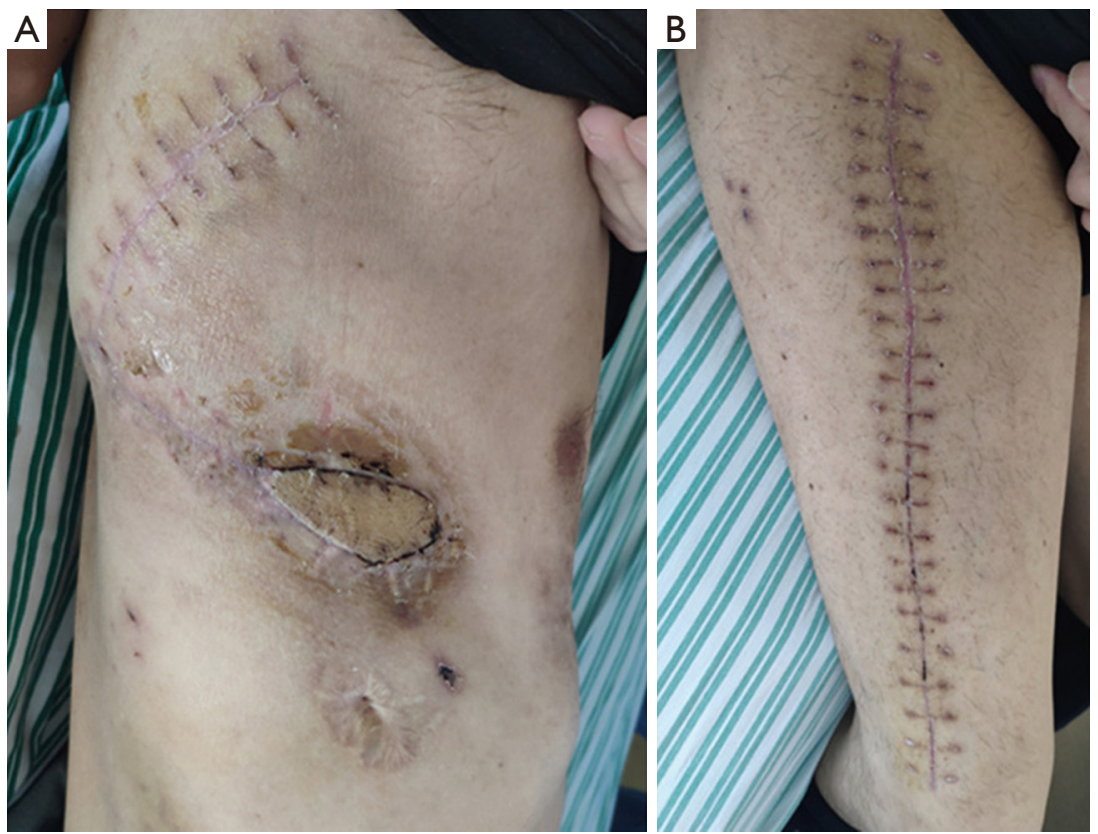

Figure 3 Postoperative incision images 3 weeks after surgery. (A) An excellent cosmetic appearance without malformation of thoracic shape.

(B) The incision of the right lower limb healed smoothly, and the movement was normal.

second, indicating that the capillary reaction time is normal), and swelling.

(III) Smoking was prohibited in the patient room. Continue to irradiate the vascular anastomosis site with a $40 \mathrm{~W}$ baking lamp from a distance of $40 \mathrm{~cm}$, and the room temperature was controlled at 23-25 degrees.

(IV) The abduction and stretching of the upper limbs of the patient were limited to avoid traction and compression of the vascular pedicles.

(V) Good bladder and bowel function were maintained.

(VI) It was important to strengthen the patient's nutrition, provide a rational diet, and prevent the occurrence of pressure sores.

\section{Results}

All eight patients had no recurrence of empyema and BPF after the procedure (Figure 3). Postoperative magnetic resonance imaging (MRI) (Figure 4) or chest computed tomography (CT) showed that the abscess cavity was basically obliterated with the well-survived flaps. No serious complications occurred during the perioperative period, and no blood vessels were re-explored due to venous or arterial thrombosis, flap necrosis, or infection. One patient

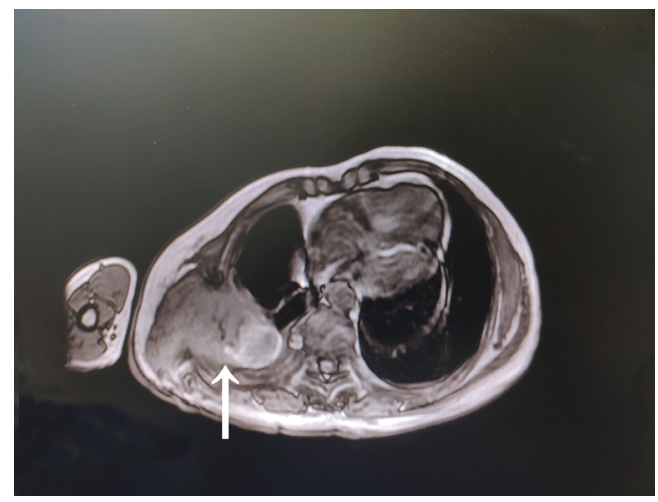

Figure 4 Follow-up chest MRI at 1 month after surgery showing that the abscess cavity is filled with the muscle flap.

had hematoma in the incision of the lower limb, which was cured after proper incision, drainage, and compression bandaging. The mean operative time was 5.19 (range, 4.56.5) hours, the average intraoperative blood loss was 306.25 (range, 250-400) $\mathrm{mL}$ and the average length of hospital stay was 46.00 (range, 31-60) days. The 18-72-month follow-up showed no obvious dysfunction in any donor lower limbs, and patients could walk and jump normally (Table 2). No recurrence of empyema was reported. The patients had an improved nutritional status and weight increased. Their 
Table 2 Operative outcomes

\begin{tabular}{lc}
\hline Variable & Patients $(\mathrm{n}=8)$ \\
\hline Sex (male/female) & $6 / 2$ \\
Side (right/left) & $6 / 2$ \\
Ages (years) & $54.75 \pm 12.12[30-70]$ \\
Times of surgery performed & $3.88 \pm 0.64[3-5]$ \\
before & \\
Time since onset of empyema & $30.63 \pm 27.20[5-74]$ \\
(months) & \\
Operating time (hours) & $5.19 \pm 0.75[4.5-6.5]$ \\
Intraoperative blood loss (mL) & $306.25 \pm 67.81[250-400]$ \\
Hospital stay (days) & $46.00 \pm 9.38[31-60]$ \\
Follow-up time (months) & $44.88 \pm 15.39[18-72]$ \\
\hline
\end{tabular}

daily activities returned to normal.

\section{Discussion}

Empyema is a rare but serious complication after lung resection, with an incidence of approximately $2-10 \%$, and can occur in the early postoperative period or several years later. Approximately $80 \%$ of $\mathrm{PPE}$ patients have $\mathrm{BPF}$. The treatment is difficult, the course of the disease is often protracted, and it may become chronic refractory empyema $(1,4)$. The main reasons chronic refractory empyema is difficult to treat include the persistent abscess, recurrent infection of the residual cavity, and BPF. Therefore, the key to its treatment is to eliminate the infectious residual cavity, close BPF, and eliminate the abscess cavity.

The treatments are as follows: (I) Rib resection with drainage or OWT. (II) Thoracoplasty. (III) Obliteration of the residual cavity with an autologous tissue flap (5-7). The first two methods have practical limitations. Autologous tissue flap transplantation has become popular in recent years. The key to successful surgery is to ensure the vitality of the tissue implanted in the abscess cavity. The choice of the pedicled tissue flap depends not only on the availability of the tissue flap but also on the location, size, and shape of the abscess cavity. The application of free muscle flaps is relatively less restrictive and is more suitable for patients who have undergone multiple operations in the past and have a severely damaged chest.

An important part of treatment is thorough control of pleural cavity infection. In 1963, Clagett and Geraci proposed a two-stage treatment plan for chronic empyema: chest drainage or OWT and repeated washing of the infected abscess cavity with antibiotic solution. Some patients are treated successfully with satisfactory results (8). However, approximately $12-80 \%$ of patients have recurrence of empyema, mainly due to incomplete removal of the necrosis in the thoracic cavity and dead space in the abscess cavity. Later, Pairolero et al. improved on Clagett's surgical procedure, adding the steps of implanting the pedicled muscle flap in the chest to reinforce the bronchial stump (9). According to their reports, the total effective rate reached $84 \%$, but the operation was difficult and was associated with a long hospital stay.

Permanent OWT has definite curative effect, can effectively control infection, and has been praised by some experts (10). Its disadvantage is that long-term dressing change is needed until healthy granulation tissue gradually appears in the pleural cavity. However, there were a series of problems, such as poor quality of life of patients, scoliosis, physical deformation, high mental stress, and reduced cardiopulmonary function in the long term. In our hospital, the first surgical procedure performed was chosen according to degree of infection in the empyema cavity. Patients with mild contamination underwent rib resection whereas patients with severe infection underwent OWT procedure. For these eight patients, rib resection drainage were performed in three patients, and continuous irrigation with dilute iodophor solution for 2 weeks postoperatively. OWT were performed in five patients (Including two cases which underwent surgery in other hospitals), dressings with iodoform gauze were done daily for 3-4 weeks. During this period, patients were instructed to strengthen their nutrition and eat a high-protein and high-vitamin diet to improve the body's immunity and control chest infections, in order to provide good conditions for the secondstage operation.Another key factor for the success of the operation is the management of the fistula. In recent years, interventional bronchoscopy has shown certain advantages. The effectiveness of fistula closure is affected by various factors, such as the size of the fistula, the underlying diseases, the blood supply of the bronchial stump, and the degree of intrathoracic infection. Therefore, it should be based on the size of the fistula and the situation of bronchial stump to select a treatment (11). The method used in this study was to first perform bronchoscopy and surgery to determine the number and diameter of the fistulas, and then close them during the obliteration surgery. In this study, 
there were four patients with pulmonary surface fistula less than $3 \mathrm{~mm}$ in diameter, which can be closed by injection of medical glue under direct vision. When the fistula diameter is greater than $3 \mathrm{~mm}$, endoscopic interventional treatment is required. Different closure materials can be used according to conditions. In this study, two of the eight patients had undergone interventional closure in other hospitals, and two patients first received EBV implantation and closure under bronchoscopy and the air leakage was significantly relieved after that. It's worth noting that the success of muscle flap transplantation is closely related to whether the fistula is closed completely. Large air leakages may cause extensive subcutaneous emphysema under mechanical ventilation during anesthesia or forced coughing, which prevents the flap from sticking to the cavity wall. Long-term air leakage after the operation makes it difficult to remove the drainage tube and eventually may cause the recurrence of the residual cavity and atrophy of the free muscle flap, leading to the failure of the procedure.

The two major methods of eliminating the residual cavity are reducing the volume of the chest cavity and filling the abscess cavity with tissue flaps. The former is mainly thoracoplasty, which has problems such as large trauma, shape changes of the chest, a long treatment time, and many other complications. It has been rarely used in the clinic. The application of extrathoracic muscle flaps into the thoracic cavity can effectively eliminate empyema and the residual cavity (12-14).

The treatment of empyema with a muscle flap and myocutaneous flap can be divided into two categories: pedicled muscle flap and free muscle flap. Pedicled latissimus dorsi, omentum, pectoralis major muscle, and serratus anterior muscle flaps are the first choices, but some patients with chronic empyema often have undergone multiple thoracic surgeries, including pneumonectomy, thoracic drainage, OWT, and modified thoracoplasty, which result in the transection of the chest wall muscles and destruction of the blood supply. Thus, most of the local muscle flaps of the thoracic cavity cannot be used or are too small. Compared with pedicled muscle flaps, free muscle flaps can be used to close a large empyema cavity, are not restricted by the rotation of the root of the muscle flap, and are easy to place into the abscess cavity. It can make full use of all the tissues of the muscle flap without waste (15). The vastus lateralis muscle flaps and musculocutaneous flaps have been clinically used for many years and are widely used in the repair and reconstruction of soft tissue defects of the limbs and oral and maxillofacial regions. The blood supply and anatomy of these flaps are quite clear, with few variations.

The vastus lateralis muscle is mainly supplied by the descending branch of the lateral femoral circumflex artery. It has many advantages, such as large volume, easy dissection, and small impact on the donor site after removal. According to the size of the abscess cavity, it can also be used in conjunction with the rectus femoris $(16,17)$. There is basically no problem of insufficient muscle volume, therefore, there is no need for additional thoracoplasty. It has a good effect on thoracic shape and cosmetic appearance of wound scar. Although free myocutaneous flaps have many advantages in practical use, they are often not the first choice. The main reasons are as follows: (I) it creates a large surgical trauma and requires microsurgery for vascular anastomosis, which is a complicated operation and requires multidisciplinary cooperation. (II) It brings a risk of muscle flap necrosis after free muscle flap implantation. (III) Poor general condition, severe hypoproteinemia, severe anemia, and severe atherosclerosis in elderly patients are contraindications for this type of surgery.

\section{Conclusions}

In summary, we believe that free vastus lateralis muscle flap transplantation is an ideal surgical method for the treatment of PPE. However, it is particularly important to choose suitable patients. The major indications include large abscess cavity, severe local muscle tissue damage, good vascular conditions, and high appearance expectation for the thoracic shape.

\section{Acknowledgments}

We would like to thank our colleagues at the Departments of Orthopedics Surgery and Anesthesiology for their support.

Funding: None.

\section{Footnote}

Reporting Checklist: The authors have completed the AME Case Series Checklist reporting checklist. Available at http://dx.doi.org/10.21037/apm-21-261

Data Sharing Statement: Available at http://dx.doi. org/10.21037/apm-21-261

Conflicts of Interest: All authors have completed the ICMJE 
uniform disclosure form (available at http://dx.doi. org/10.21037/apm-21-261). The authors have no conflicts of interest to declare.

Ethical Statement: The authors are accountable for all aspects of the work in ensuring that questions related to the accuracy or integrity of any part of the work are appropriately investigated and resolved. The study was conducted in accordance with the Declaration of Helsinki (as revised in 2013). The study was approved by institutional ethics board of Tongde Hospital of Zhejiang Province (No.KTSC2017229) and individual consent for this retrospective analysis was waived.

Open Access Statement: This is an Open Access article distributed in accordance with the Creative Commons Attribution-NonCommercial-NoDerivs 4.0 International License (CC BY-NC-ND 4.0), which permits the noncommercial replication and distribution of the article with the strict proviso that no changes or edits are made and the original work is properly cited (including links to both the formal publication through the relevant DOI and the license). See: https://creativecommons.org/licenses/by-nc-nd/4.0/.

\section{References}

1. Eckersberger F, Moritz E, Klepetko W, et al. Treatment of postpneumonectomy empyema. Thorac Cardiovasc Surg 1990;38:352-4.

2. Jiang L, Ding J, Gao W, et al. Therapeutic progress for chronic empyema by filling with muscle and musculocutaneous flaps. Chin J Surg 2007;45:1145-7.

3. Tsai FC, Chen HC, Chen SH, et al. Free deepithelialized anterolateral thigh myocutaneous flaps for chronic intractable empyema with bronchopleural fistula. Ann Thorac Surg 2002;74:1038-42.

4. Schneiter D, Cassina P, Korom S, et al. Accelerated treatment for early and late postpneumonectomy empyema. Ann Thorac Surg 2001;72:1668-72.

5. Cardillo G, Carbone L, Carleo F, et al. The rationale for treatment of postresectional bronchopleural fistula:

Cite this article as: $\mathrm{Wu} \mathrm{Y,} \mathrm{He} \mathrm{Z,} \mathrm{Zhang} \mathrm{C,} \mathrm{Liu} \mathrm{Y,} \mathrm{Xu} \mathrm{W,}$ Chen G, Liu Z, Xin S, Wang L. Free vastus lateralis muscle flap transplantation for postoperative chronic empyema: retrospective analysis of eight case series. Ann Palliat Med 2021;10(5):5046-5054. doi: 10.21037/apm-21-261
Analysis of 52 patients. Ann Thorac Surg 2015;100:251-7.

6. Andreetti C, Menna C, D'Andrilli A, et al. Multimodal treatment for post-pneumonectomy bronchopleural fistula associated with empyema. Ann Thorac Surg 2018;106:e337-9.

7. He Z, Shen L, Xu W, et al. Analysis of individualized comprehensive therapy for patients with bronchopleural fistula accompanying refractory empyema. Chin J Thorac Surg 2020;7:40-3.

8. Clagett OT, Geraci JE. A procedure for the management of postpneumonectomy empyema. J Thorac Cardiovasc Surg 1963;45:141-5.

9. Pairolero PC, Arnold PG, Trastek VF, et al. Postpneumonectomy empyema. The role of intrathoracic muscle transposition. J Thorac Cardiovasc Surg 1990;99:958-66; discussion 966-8.

10. García-Yuste M, Ramos G, Duque JL, et al. Open-window thoracostomy and thoracomyoplasty to manage chronic pleural empyema. Ann Thorac Surg 1998;65:818-22.

11. Jiang T, Han X. Progress in interventional treatment for bronchopleural fistula. Henan Med Res 2018;27:2194-5.

12. Seify H, Mansour K, Miller J, et al. Single-stage muscle flap reconstruction of the postpneumonectomy empyema space: The Emory experience. Plast Reconstr Surg 2007;120:1886-91.

13. Qu J, Li J, Xie B, et al. Autologous myocutaneous flap implantation for chronic refractory empyema: 26 cases report. Chin J Cardiovasc Surg 2018;34:613-6.

14. Lu C, Feng Z, Ge D, et al. Pedicle muscle flap transposition for chronic empyema with persistent bronchopleural fistula: Experience of a single clinical center in China. Surg Today 2016;46:1132-7.

15. Shen L, Guo Y, He Z. Treatment of huge empyema by free anterolateral thigh flap transplantation: Analysis of 3 cases. Chinese Journal of Plastic Surgery 2018;34:1044-7.

16. Saint-Cyr M, Schaverien M, Wong C, et al. The extended anterolateral thigh flap: Anatomical basis and clinical experience. Plast Reconstr Surg 2009;123:1245-55.

17. Tsai YT, Chen CC, Lu HI, et al. Free anterolateral thigh combined flap for chronic postpneumonectomy empyema. Ann Thorac Surg 2010;90:651-4. 